\title{
Communications Environment in Africa
}

\author{
By Thomas Namreaga and Joseph Healey
}

\section{Introduction}

A Canadian White Father in Uganda said: "I would give 20 years of my life for a 30-second bicycle ride through the mind of an African." A Kenyan layman said: "We Africans have forgotten the traditions and customs of our grandparents." After working 30 years in Zambia an Irish Capuchin priest advised a newly-arrived priest: "Here in Africa you should live with a sense of humor and a sense of wonder." President Julius Nyerere of Tanzania said: "We have problems but we remain cheerful."

These four quotations provide insights into understanding the mentality and milieu of Africa. Missionary priests, brothers, sisters and lay people are constantly faced with the great challenge of understanding the African environment. And Africans themselves are faced with the challenge of better understanding their own environment with its rich variety of customs and traditions $\mathbf{1}^{\mathbf{1}}$.

\section{Meaning of time in Africa}

The African concept of time is very different in some aspects from the Western concept of time when everything can be planned "down to the last second." In Africa time is more flexible, more relative. One Kenyan priest said: "Time does not exist in the Reserve (the traditional African area)." Many Africans in rural areas tell the time by the sun rather than by a watch or clock. A person can save a lot of worry and frustration by adjusting to this flexible time pattern.

Some examples:

Local government leaders call a meeting for 8:00 a.m. but the people arrive at 9:00 a.m. or 10:00 a.m. or even 11:00 a.m. Everyone seems to adjust to this flexible timetable.

There is a Swahili expression "Tutafika tu" (which in English means "we will come"). The speaker may use this expression figuratively without actually intending to come. The nuance of the speaker's voice is important for the meaning of the words too.

Once Bishop Christopher Mwoleka, Bishop of Rulenge Diocese, and I drove from Mwanza to Rulenge. Outside of Mwanza we had to wait for one and a half hours at the KigongoBusisi Ferry at Bukumbi. After discussing what this waiting meant we decided that a person could have three possible attitudes:

1. Frustration, impatience and annoyance at the delay. The one and a half hours was just a waste of time.

2. Fill up the time as usefully as possible: read a book, write letters, talk to a friend.

3. Share the wait with the ordinary people as a "ministry of spiritual presence."

The ordinary people are constantly waiting. The lorry drivers at the Kigongo-Busisi Ferry had to wait up to eight hours before crossing. Women with babies in their

Father Namwaga is a diocesan priest who is Director of Social Communications in the Diocese of Mwanza (Tanzania). Father Healey was Social Communications Secretary of AMECEA for six years and presently is working in Rulenge Diocese (Tanzania). 
arms have to wait three days before getting a bus from Mwanza to Shinyanga. There is sometimes a two-week wait in getting a bus from Mwanza to Bukoba. In all these "waiting situations" we can identify with the people in their hardships and sufferings.

A missionary priest in Tanzania has written: "I am making five year plans in a rural community whose remote future doesn't go beyond the next harvest, or the next rainy season, that is six months at the most. (I say) time is pressing, we must act quickly, tomorrow will be too late. And so I push and push, I get impatient and I come up against a polite wall of silence, a rubber wall, pliable, flexible, but impenetrable. If I push too strongly, the wall will bounce me badkwards, and I am liable to do myself an injury as I fall. Once again I wanted to impose my views, my feelings of urgency, until the day a friend gently told me: 'Why do you weep before your grandmother is dead?' As for me, I am thinking: 'Perhaps there is still time to save grandmother if we act quickly.' But it is not my grandmother, it is his."

Related to the African meaning of time is the person-centered culture in Africa. One missionary priest in Tanzania has written: "At the beginning in the parish I was prisoner of my 'motor-bike' and keen on speeding. But one fine day I realized that I was traveling at 40 kilometres an hour in a community that traveled on foot or on bicycle. So I gave up my 'motor-bike' for the 'bike'. My relations changed immediately. I discovered a new sense of time and distance. I was no longer alone on the road and I took time to stop and visit my friends along the road."

In Musoma Diocese (Tanzania) I attended a big celebration to welcome the new Mother General of the Immaculate Heart Sisters, the local congregation of African sisters. The songs, dances, plays and poetry lasted for five hours. All the Africans seemed very happy to participate in the whole celebration. At the beginning I counted over 20 expatriate priests, sisters and lay people. But as the hours went on they started to leave until at the end only three expatriates were left.

\section{Greetings in Africa}

From the beginning of time people everywhere in the world have been greeting one another. Basically and initially, the act of greeting is the beginning of communication between one person and another. But the meaning of greetings has differed from one nation to another according to changing customs and traditions. Among some people it has become a stiff and ceremonious ritual before which one has to undergo a certain rehearsal.

In Africa the tradition of greeting is an important part of social life. It is through greeting that one person starts exchanging ideas with his or her neighbor. Greeting for an African is the beginning and extension of relationship with other people. It does not entail or demand any special ceremony before taking place. The purpose of greeting is to establish a relationship, not just get information.

Often if two expatriates meet for the first time they will not greet each other until they have been introduced by a third party. Unless they are introduced to each other they could rub shoulders year in year out in the same office without a word of "Good Morning."

A few years ago one White Father priest told us in class that when he was studying in England he used to go to the library to read. In that library he used to meet a certain person. But since he had not been introduced to the person he dared not say "Good Morning." The priest remained in this situation for eight years simply because he had not been formally introduced.

Such a thing for an African would be unthinkable. When an ordinary African meets another person the first thing he does is to stop, say a few words of greeting to the person and 
exchange familiarities. He will ask the person how he or she is, how he or she feels, how everyone at home spent the night and how eceryone got up in the morning. By doing so the African is creating "relationship" - extending his circle of friends especially if the person being greeted is from a distant region.

To an expatriate all these exchanges may seem a waste of time and superfluous. While an African will use the word "Jambo" for "How are you" he will not use it as curtly as some expatriates do. Many expatriates will simply say "Jambo" to an African and then disappear or keep quiet. The expatriate may not stop to inquire who the one he is greeting is, how he feels, where he comes from and where he is going.

To many Africans such behaviour indicates that the expatriate is proud or simply does not value the African as his fellow social human being - or perhaps that he doesn't know the particular African language well.

An African priest in Tabora Archdiocese (Tanzania) said that when he sees a person enter a circle of people and immediately starts saying "Jambo" to each of the people, the person is either a politician or an expatriate.

The Baganda people in Uganda have a very long greeting pattern. The initial exchange of greetings and informal questions and answers can last for a considerable length of time depending on the relationship of the people involved in the greeting.

When meeting someone for the first time in the day or at a particular part of the day, one should greet before saying anything else. Even when reproaches are to be made, greetings should be exchanged first.

Africa has a person-centred rather than a task-oriented culture. So extended greetings is a very important part of the "small talk" before starting business.

A good insight into the person-to-person style of communications in Africa is contained in the proverb: "A letter is half as good as seeing each other."

\section{Meaning of Words: Exact Meaning vs. Convention}

Language is one of the most powerful means of communication between people. In order that man communicates effectively and meaningfully, the tools of his language i. e. his words must be properly used and understood. If the words used in a language are vague or full of double meanings, communications becomes very difficult and even impossible.

It is therefore very important for both the person using the words and the person hearing them to understand the proper meaning and use of these words. Words can be used either in their "exact" meaning or in their "conventional" meaning.

A Swahili² expression that can cause misunderstanding between expatriates and Africans are the words "Sasa Hivi" (= "Just Now" or "Right Now"). A few days ago I was looking for one priest who had come to visit us in Mwanza. When I asked a priest at Mwanza Cathedral where the visiting priest was, I was told: "Ametoka sasa hivi", (= "He has left just now"). Exactly one half hour later during lunch I asked another priest who had been with the visitor. I was told: "Padri huyo ameondoka sasa hivi" (= "That priest has left just now"). I was a little vexed by the answer because I knew that the visiting priest had left one half hour before and yet that lapse of time was still "Sasa Hivi".

If you are hurrying to the Serengeti and the spring of your car breaks, you might be consoled by the garage mechanic who says that your car will be repaired "Sasa Hivi". Your great expectation to leave very soon for the Serengeti, however, will turn into a big disappointment when after an hour or so the spring is not yet fixed or replaced with a new one. In such cases the words "Sasa Hivi" are used by convention and for the sake of encouragement. 
Another time word is "Baadaye" (= "Afterwards"). Depending on the situation and context it can mean after a short time or after a long time.

"Kesho" (= "Tomorrow") has a similar flexibility and variability. Very often it does not mean the 24-hour period starting at midnight tonight. It often means some time in the future - tomorrow, in three days, next week, etc. A person might say out of politeness: "I will come 'kesho' (= 'tomorrow') referring to some time in the near future."

During a two-month period in Nyabihanga Ujamaa Village, 18 kilometres from Rulenge in Western Tanzania I wrote down the different uses of "Zamani" (= "long ago" or "a period of time"). "Zamani" was used to refer to:

1. 2000 years ago. E. g. the birth of Christ.

2. 10 years ago. E. g. the writing of the Arusha Declaration.

3. Last year. E. g. the time a certain man moved into the village.

4. 3 weeks ago. E. g. when the head of Rulenge District visited Nyabihanga.

5. Last week. E. g. when we finished planting maize.

6. Yesterday. E. g. when a schoolboy recovered from malaria.

Soon afterwards I visited Mwanza. While having a cup of tea with some White Fathers I asked one of the priests if he wanted another cup. He answered: "No, thank you, I finished 'zamani'." (Meaning three minutes ago.)

"Ndiyo" (= "Yes") is another word that can be used in many contexts. "Ndiyo" is sometimes called the "polite yes." The person giving consent does not really mean agreement or affirmation. Since he is afraid of offending the person concerned he says "Yes" out of politeness.

A certain priest wanted to convert a chief who had many wives. The priest talked about God and how $\mathrm{He}$ loved the world so much that $\mathrm{He}$ sent $\mathrm{His}$ only Son to save the world. The priest asked the chief if he understood and believed all this and the chief said "ndiyo." When the ppriest asked the chief to send away his wives, the chief said that he would think it over.

After some years another priest went to this chief with the same message and asked the chief if he was ready for baptism. The chief said "ndiyo." Yet the chief died unbaptised. The chief respected the priests and did not want to disappoint them by saying "no" to them. He kept postponing the day of his baptism although he said "ndiyo" (= "yes").

When I first came to Africa and asked a sick person how he or she was feeling I would get the answer: "Nzuri kidogo" (= "Good, a little"). I soon learned that Africans used "Nzuri" as a standard reply, even when later they would qualify the meaning of "good" with other expressions. This is part of the cheerful optimism of the African character.

The words "Karibu" (= "Near") and "Mbali" (= "Far") often have to be understood in a figurative or relative sense. When asking directions to a certain village I have been told that it is "karibu sana" (="very near"). Then I drove on for 5 miles before actually reaching the village. This sense of "relativity" is expressed well in the Swahili proverb: (English translation) "The water in a coconut-shell is like an ocean to an ant."

To understand the communications environment of Africa it is helpful to learn the meaning of African idiomatic expressions. As in every language idioms use words in a figurative sense. Three interesting Swahili examples:

1. "Amekula chumvi nyingi" (= "He or she has eaten much salt"). MEANING: An old man or old woman.

2. "Amevaa miwani" (= "He wears glasses"). MEANING: He is drunk. 
3. "Hajapata jiko" (= "He does not have a stove"). MEANING: He is not married yet.

Negative answers are common in African languages. Examples are: "Si Mbaya" (= "It is not bad") and "Hamna Taabu" (= "There is no problem").

\section{Repetition}

Repetition is very common in the African tradition. For the Westerner repeating the same thing many times may seem to be a waste of time and unnecessary, but in Africa it is important that each person has his or her say.

I once celebrated Mass for the intention of a Postulant Mistress of the Immaculate Heart Sisters (Tanzanian Congregation) who was making her final vows. Each postulant (12 in all) gave her own petition for the professed sister during the Prayers of Intercession. Most of the intentions were the same: asking God's blessing for the sister. But it was important that each postulant gave ber own petition as an expression of her regard and concern for the Postulant Mistress.

At African funerals many people may give a short talk praising the deceased person. While these talks repeat themselves it is important that each speaker has his or her chance. An African priest in Nairobi Archdiocese was once officiating at a burial service. Under the burning sun the speeches for the deceased person went on and on. The priest was hot, tired and thirsty. When finally the priest was called upon to say a prayer, all he could think of was to pray for rain.

Music in Africa is generally not played for its own sake; it is usually played in connection with certain great events happening in life. Music may be played at religious and social ceremonies or at ceremonies connected with birth or death.

The melody and rhythm in African music and dance are often repetitive. This is done on purpose in order to "make the people act together and feel more strongly about the event being celebrated," as one author puts it. Not only are rhythms and melodies repeated in African music but also the drumming. A drummer plays a simple repetitive pattern because he wants to set a pace of time of the music so that the dancers may know exactly when to make such and such movements.

During a meeting a speaker will support a previous speaker (in Swahili "kuunga mkono" means "to support") by repeating the same thing. The people are not concerned about the repetition or the long length of the meeting.

\section{Question and Answer Style}

The Western method of direct questions and answers is foreign to many people in Africa. Africans have a much more casual and indirect style of using questions e.g. as part of lengthy greetings: How did you spend the night? How is your home? How are your children, etc.? But to ask questions purely for information is not customary. People might give you the answer that they think you want rather than the correct answer.

I once accompanied Bishop Christopher Mwoleka on a census of the Christians in Nyabihanga Ujamaa Village. Even though he knew many of the people and used Shubi, the local language, the bishop had a lot of trouble getting exact information from the people e.g. the number of children in one family (children who have died are often included in the total number given); which children belong to which wives (many men take a second wife in this village); details about baptism, etc. Accuracy is very difficult because the extended family is sometimes included in the statistics; in some places there is a taboo about counting the children. 
In this same village a Zairean Little Brother of Charles de Foucauld tried to sort out a marriage case. After one half hour of asking questions he gave up - saying that he knew less about the case at the end of the question period than at the beginning.

I once tried to settle a marriage case in Mwanza Diocese. During my conversation with the husband and wife the woman went into a long explanation without getting to the point of the couple's difficulties and without answering my questions about the case.

Western research style can be misleading, even disastrous in Africa. Many Africans are not comfortable with the cold, impersonal style of a questionnaire. A person-to-person interview is often more effective.

\section{Meaning of Laughter}

Everywhere in the world people laugh briefly or at length to express outwardly the joy they are experiencing within themselves. The causes of laughter are many. It is the cause of the laughter that makes the big difference in understanding the meaning of laughter for Africans and for expatriates.

For the African, and for the expatriate too, anything funny or very pleasing may cause laughter. A sad event or an awkward happening may also cause laughter on the part of the African. Take the example of a person who is being chased by a swarm of bees and is running about frantically in order to get away. Africans meeting him or witnessing the scene will usually, at first sight, break into big laughter. When they discover that the victim is really overwhelmed or overpowered by the insects, then at that moment they will feel great compassion.

When the people witnessing this sad scene spontaneously break into laughter they are not trying to enjoy the sad plight of the victim. What makes them laugh are the funny and incongruous circumstances in which the victim has unexpectedly been placed: the sudden commotion and the abrupt breaking of a peaceful situation that the victim has been enjoying.

An expatriate, without much experience and understanding of Africans, may be critical of people who laugh at a victim in a case such as the bees. But when an African laughs at such a sad incident it is not because he or she enjoys suffering but because he or she experiences a certain incongruity in the sad events taking place at that moment. The lack of harmony in the sequence of events will make the African laugh.

Some other examples where Africans laugh at incongruity or lack of harmony:

1. A very destitute person in tattered clothes enters late into a party. This will cause great laughter among Africans.

2. Someone falls from a roof: first there is laughter, then sadness.

3. In class a student makes a big mistake while answering a question and the teacher corrects him or her. All the students laugh. The expatriate teacher might think that the students are laughing at the teacher; but in fact they are laughing at the incongruous situation.

When a film or slides are shown on the crucifixion of Christ, Africans may laugh while Westerners consider this a very solemn, sad moment. The Africans are expressing their emotions and feelings at the great incongruity. As an African student told me: "If I did not laugh I would have to cry." 
I used to show a Maryknoll film on Tanzania called "Of People and a Vision." I did research on approximately 40 showings. African audiences laughed the most:

1. When scenes were shown of people eating (normally a private event).

2. Close-up shots of people with big smiles showing their white teeth.

\section{Logic of an African}

Is there such a thing as an African Philosophy? There might be as many answers as there are nations or ethnic groups in Africa. Logic, as a part of philosophy and as an art of orderly thinking, has different aspect according to how it is understood and applied by one group of people or another. The way one person orders his steps of thinking will differ from that of his neighbor according to the system of education and the environment in which he has been brought up.

While many of the white man's cultural backgrounds are influenced by one systematic philosophy or another, the black man's cultural background is mainly influenced by natural philosophy. The logic of an ordinary educated expatriate might be patterned on Thomistic, Aristotelian or Existential Philosophy. That of the ordinary educated African will be practically patterned on natural philosophy.

One day I visited an African friend of mine who is well educated and financially well off. I noticed that his three children had no shoes and were playing in the mud outside. I said that unless they played with shoes on they might catch cold and get pneumonia. My friend answered that if they got sick he would take them to the hospital. In this case the logic of "prevention is better than cure" was not clear in his head. Although implicitly he knew the saying and its logical application, its explicit and practical application was impossible for him although he had sufficient money to buy shoes for his children.

While working in an office in Kampala $I$ asked James, the switchboard operator, to buy some milk. The cost was 4 shillings and 20 cents. Not wanting a lot of small change I gave James a 5 shilling note and 20 cents - expecting a shilling in return. James handed me back the 20 cents and said: "Father, I don't need this; 5 shillings is enough."

A Malawian communications specialist told me that, in general, Africans do not anticipate future activities and events. They live one day at a time. I have discovered this in Nyabihanga Ujamaa Village. I live with two Tanzanian schoolboys who never worry about a "reserve supply."

If they get a gift of 2 kilos of fresh meat they eat it immediately without thinking how the precious meat could be spaced over three or four days. To build up a stock pile of firewood is just not the boys' type of planning. When they run out of firewood they simply go out and look for more without anticipating a rainy day or darkness or unexpected visitors. They live intuitively rather than systematically. Yet adults will usually have a reserve pile of firewood.

It can be embarassing and inconvenient when you suddenly need toilet paper only to have the houseboy say: "I was waiting until you ran out of toilet paper. Then I would go to the store and buy some more." It might not occur to him to keep a reserve supply on hand. This may be a personal characteristic. I know of an expatriate who used to get stuck on the road because he would run out of petrol.

Many Africans are not used to pursuing the logical and ultimate reasons or causes of events taking place around them. They either take them for granted or attribute them to the highest cause (God). A certain man was going to hospital and while at the bus-stand he died. A hotel keeper who witnessed the event was asked by a radio reporter how and why that man died. He answered by saying: "Amekufa sababu ya Mungu tu" ("It is only by God's action that he died.") 


\section{Conclusion}

We have tried to examine the Communications Environment of Africa through real-life examples and situations rather than through scientific theories. There are significant differences in the traditions, customs, outlooks and attitudes of Africans and expatriates. Both Africans and expatriates should be aware of the differences in their mentalities and communications styles. It is important to respect and appreciate each other's ways of thinking, customs and traditions.

\section{Notes:}

1. This article presents the personal observations, impressions and reflections of the two authors. Particular examples and cases are used which may not be representative of all parts of Africa. After further research and consultation this article will be revised and put into final form.

2. In this article examples are used from the Swahili language. Similar examples can be found in many other African languages.

\section{ZUSAMMENFASSUNG}

Die persönlichen Erfahrungen des afrikanischen Leiters des Kommunikationsbüros der Diözese Mwanza und des früheren Leiters des Kommunikationsbüros der Vereinigung der Bischofskonferenzen des östlichen Afrika (AMECEA), der jetzt in einem Ujamaa-Dorf Tansanias lebt, sind hier wiedergegeben. Sie versuchen das Umfeld und die Erscheinungsweisen der Kommunikation in afrikanischer Gesellschaft in sieben Themenkreisen zu erfassen und durch Einzelbeispiele zu belegen:

1. Der afrikanische Zeitbegriff ist gegenüber dem Westen, wo alles bis zur letzten Minute geplant wird, mehr flexibel und relativ. „Zeit gibt es nicht im Reservat“ (dem traditionellen afrikanischen Stammgebiet), sagte ein kenianischer Priester; viele Afrikaner zählen die Zeit nach der Sonne und nicht nad der Uhr. Die einfachen Leute warten ständig und dieses Warten gehört zum täglichen Leben. Man kann ihm gegenüber drei Einstellungen haben: Entweder man ist frustriert, ungeduldig und böse über die Verzögerung; oder man füllt die Wartezeit mit nützlichen Dingen aus, wie Lesen, Briefeschreiben, Unterhaltung; oder man teilt die Wartezeit mit den einfachen Leuten als Zeichen der Gegenwart mit diesen Menschen - eine ausgezeichnete Gelegenheit zur Kommunikation.

2. Das Grüßen ist überall Beginn einer Kommunikation zwischen Personen, allerdings ist es oft zu einer Formel erstarrt. In Afrika ist das Grüßen aber immer noch ein bedeutender Teil des gesellschaftlichen Lebens. Mit dem Gruß beginnt ein Meinungsaustausch, und dieser erfordert keine besondere Zeremonie. Ziel des Grußes ist es, eine Beziehung zu schaffen, nicht nur, Information zu erlangen.

3. Die Bedeutung von Wörtern und Ausdrüdken ist auch in afrikanischen Sprachen unterschiedlich. So sind vor allem die Ausdrüdre für Zeitabstände etwa im Suaheli meist wesentlich ungenauer, als wir im Westen gewohnt sind. Wer in Afrika lebt und arbeitet, sollte sich um eine genaue Kenntnis der Idiome afrikanischer Sprachen bemühen.

4. Die Wiederholung der gleichen Sache ist sehr häufig in der afrikanischen Tradition. Jede Person etwa in einem Gespräch muß die Gelegenheit zum Sprechen haben, auch wenn immer wieder das Gleiche gesagt wird. Dies gilt auch für die Musik und den immer wiederholten gleichen Rhythmus, etwa auch beim Tanz. 
5. Die westliche Art der direkten Frage und Antwort ist vielen Afrikanern fremd. Sie bevorzugen einen mehr indirekten Fragestil, der uns oft umständlich erscheint. Dabei werden sie oft jene Antwort geben, die sie als vom Fragenden erwartet ansehen.

6. Gelächter wird in Afrika als Ausdruck der Freude gebraucht, aber das Lachen kann einem auch bei ernsten Dingen begegnen, wenn sie in irgendeiner Weise als komisch erscheinen.

7. Afrikanische Logik ist nicht jene westlicher Philosophien. Sie beruht auf der Naturphilosophie und wird von den Erfahrungen des afrikanischen Alltags bestimmt. So werden z. B. zukünftige Entwicklungen oft nicht vorausgesehen. Entsprechende Planung ist schwierig.

Die Autoren sind sich bewußt, daß sie nur versuchen, praktische Erfahrungen pragmatisch zusammenzutragen, ohne dabei den Anspruch auf Wissenschaftlichkeit zu erheben.

\section{RESUME}

Ici sont restituées les expériences personnelles de l'administrateur africain du bureau de communication du diocèse de Mwanza et de l'administrateur précédent du bureau de communication de l'association des conférences des évêques d'Afrique Orientale (AMECEA) lequel vit maintenant dans un village Ujamaa de Tanzanie. Ils essaient d'inventorier le rayon d'action et les modes de manifestation de la communication dans la société africaine à l'aide de sept sujets de discussion et ils essaient aussi de donner des exemples isolés à l'appui. Ces sujets de discussion sont: la signification de la notion de temps, le salut, la signification d'expressions grammaticales, la répétition de parole et musique, le style de demande et réponse, la signification du rire et la logique propre de la mentalité africaine. Les auteurs sont conscients du fait qu'ils ne font qu'essayer de réunir de façon pragmatique des expériences pratiques sans pour cela émettre une prétention de caractère scientifique.

\section{RESUMEN}

Se presenta aquí la experiencia personal del director autóctono de la Oficina de Comunicación Social de la diócesis de Mwanza y del ex-director de la Oficina de Comunicación Social de la Asociación de las Conferencias Episcopales del Este de Africa (AMECEA), quien vive ahora en una aldea Ujamaa de Tanzania. Tratan de resumir en siete apartados el campo y la fenomenología de la comunicación social en la sociedad africana, ilustrándola con ejemplos. Estos apartados son: la importancia del concepto tiempo, el saludo, importancia de los giros idiomáticos, la reproducción de la palabra y la música, el estilo de pregunta y respuesta, la importancia de la sonrisa y la lógica propia de la mentalidad africana. Los autores son conscientes de que solo tratan de presentar pragmáticamente experiencias prácticas, sin pretensión científica alguna. 